\title{
Influence of Rootstocks on Scion Growth and Vigour, Production, Water Relations, Physiology and Leaf Nutrient Status of Temperate Fruit Crops-A Review
}

\author{
M.K. Sharma*, Rifat Bhat, N. Nazir, A. Khalil, S.A. Simnani and A.S. Sundouri
}

Division of Fruit Science, Sher-e-Kashmir University of Agricultural Sciences \& Technology of Kashmir, Shalimar, Srinagar (J\&K.), India

*Corresponding author

\section{Keywords}

Rootstock, Growth, production, Water relations, Nutrient uptake, Temperate fruits

Article Info

Accepted:

10 January 2019

Available Online:

10 February 2019

\section{Introduction}

Fruit trees are composed of two different individuals-the rootstock and the sciongrowing together as one. A rootstock is a stump, which already has an established, healthy rootsystem, used for grafting a cutting/bud from another plant and the tree part being grafted/budded onto the rootstock is called the scion. The scion is the plant which has the properties desired by the propagator, and the rootstock is the working part which is connected with the soil to nourish the new plant. Two parts will grow together, producing a single tree although genetically it is two different parts. The ideal rootstock should exhibit a high degree of compatibility with scion cultivars, give maximum productive life to the trees, exhibit favourable influence on the performance, bearing and quality of scion variety. The effect of rootstock on scion growth and vigour, fruit yield and quality, water relations, physiology and nutrient status is studied in temperate fruits. This review describes these effects in temperate fruits and more particularly in stone fruits. 


\section{Plant growth and vigour}

Plant growth is the increase in the size of plant by cell division and enlargement including synthesis of new cellular material and organization of subcellular organelles. Plant growth is measured in terms of increase in plant height, plant spread, plant volume and fresh and dry weight of different plant parts. Rootstock and scion cultivar greatly influence the tree vigour. Micke et al., (1996) studied the effect of peach and almond rootstocks on the growth of Carmel and Nonpareil cultivars and observed that Lovell peach rootstock produced larger trees than the other rootstocks. While studying the performance of almond cvs. Colorada and Cion Cebas grafted on Garrigues, Ramillete, Texas apd Bergasa-1 rootstocks, Egea Caballero and Burgos. Kumar (1987) reported that the trees of Dhebar, IXL, Katha, Nonpareil and Merced almond cultivars were more vigorous and larger on wild peach than on behmi and bitter almond rootstocks. Similarly, Gall and Grasselly (1979) while studying the behaviour of 12 almond varieties grafted on almond, peach and peach $\mathrm{x}$ almond rootstocks observed that peach seedling and peach $\mathrm{x}$ almond rootstocks were superior to almond seedling. Similarly, Donno et al., (1976) reported that early trunk growth in almond cvs. Tuono and Filippo Ceo were faster on the sweet almond seedling rootstock Don Carlo than on bitter almond seedling rootstock, but the difference disappeared after 8-10 years. In peach, rootstocks also exhibited variable effects on scion growth and vigour. Rana et al., (1997a) observed that peach cv. Sharbati budded on plum rootstock had the smallest trunk diameter as compared to plants produced from cuttings or on peach rootstock. Similarly, Bellini et al., (1993) observed reduced tree growth of Maycrest peach and Maria Emila nectarine grafted on plum selections. More vigour and growth was observed in Flavocrest peach plants grafted on Yugoslavian and GF 305 peach rootstocks than those on Rubira and Higama rootstocks (Salvador and Monastra, 1996), in Springlady and Redcal peaches grafted on GF677 than those on Myran rootstock (Bussi et al., 1995), in Maravilha peach grafted on Hansen 536 as compared to those raised on Mrs 2/5 (plum) or PSB2 (peach) rootstock (Car et al., 1995), in Babygold 6 peach on GF677, Oupnishka and peach $\mathrm{x}$ almond seedling rootstocks (Mitov and Oyakov, 1989), and in Golden Queen peach on Golden Queen seedlings and Myran Yumir rootstocks (Glucina et al., 1992). In peaches, peach rootstocks induced more vigorous growth than almond rootstock, while peach $\mathrm{x}$ almond hybrid induced moderately vigorous growth. Contrary to this, Dozier et al., (1983) concluded that rootstocks did not affect tree height, spread and trunk circumference in peach. Growth and vigour of the plum tree is also influenced by the rootstock used. Sitarek et al., (1995) observed that plum cvs. Empress and Valor grown on Pixy and Wangenheim prune rootstocks were less vigorous than on $P$. divaricata rootstock. Barroso and Renaud (1994) grafted six cultivars of Greengage clones and one cv. of Stanley clone on 8 rootstocks and observed very poor growth with Pixy and Citation (P. salicina $\mathrm{x}$ Peaches) rootstocks. Renaud and Salesses (1994) observed that plum cv. Greengage grafted on 13 rootstocks were more vigorous than French Prune. Kosina (1994) studied the performance of plum cv. Stanley on 5 Myrobalan clones and on Damas C clone and observed that trees on Myrobalan SE 4040 grew most vigorously than the other rootstocks. Ystass and Froynes (1993) observed highest growth of 'plum cvs. Rivers Early Prolific, Opal, Oullins Gage, Count Althan's Gage and Victoria on Myrobalan B rootstock as compare to Brompton, St. Julien A, St. Julien Seedlings and Marianna rootstocks, Similarly, Stella cherry grafted on GM9, GM6 1/1 and GM 79 was less vigorous 
than on Colt (Kemp and Wertheim, 1996). Leaf area was appreciably influenced by the rootstocks. Kumar (1987) recorded maximum leaf area in almond trees on wild peach and the minimum on bitter almond. However, irrespective of the rootstock used, Nonpareil attained the maximum leaf area while Afganistan seedling the least. Higher leaf area was also observed in apple plants grafted on M9 and MM106 rootstocks (Makariev et al., 1986), on M4 (Bhatia, 1992) and M25 rootstocks (Chandel and Chauhan, 1994). Fallahi et al., (2001) reported that 'BC-2 Fuji' apple trees on Bud.9 rootstock had shorter limbs and terminal shoots than those on Ottawa 3 and M.7 EMLA. Hrotko et al., (2001) evaluated the trees of plum cultivars 'Stanley', 'Cacanska lepotica' and 'Althan's Gage' planted on rootstocks; Myrobalan 'C 162/a' seedling, vegetatively propagated Marianna 'GF 8-1', Myrobalan 'MY-BO-1', Myrobalan 'MY-KL-A', 'St Julien' 'GF 655/2', and Prunus domestica 'Fehér besztercei' and observed that largest trees in trunk cross sectional area, canopy area and canopy volume were produced on Marianna 'GF 8-1' and Myrobalan 'C 162/a' seedling rootstocks. However trees on Myrobalan 'MY-BO-1' and Myrobalan 'MY-KL-A' were medium sized in comparison to other rootstocks and small tree size was achieved on rootstocks 'St Julien' 'GF 655/2', and Prunus domestica 'Fehér besztercei'. Sharma et al., (2004) recorded higher annual shoot growth and leaf area in Non Pareil almond cultivar than Merced cultivar when raised on wild peach than bitter almond rootstocks. Univer et al., (2006) observed that apple rootstocks B.9, B.396 and M. 26 significantly reduced vegetative growth of apple trees whereas trees on rootstock B.545 had the strongest growth. Lanauskas (2006) evaluated two plum cultivars 'Stanley' and 'Kauno Vengrine' on four rootstocks viz. Prunus ceracifera seedlings, St. Julien A, St. Julien GF 655/2 and Marianna GF 8/1 and reported that plum trees on St. Julien A and St. Julien GF655/2 reduced tree trunk diameter in comparison to Prunus cerasifera seedlings. Tworkoski and Miller (2007) reported that dwarfing rootstock M-9 had the lowest and seedling rootstock had the greatest tree height and trunk diameter in apple. Mestre et al., (2017) studied the growth of peach cv. 'Catherina' fruits raised on seven hexaploid plum rootstocks, as well as one Prunus persica seedling and observed that rootstocks GF 655/2 and P. Soto 67 AD proved to be the most dwarfing rootstocks, while Constantí 1 and Monpol were the most invigorating. Milosevic et al., (2011) conducted an experiment to determine the effects of Myrobalan rootstock and Blackthorn interstock on the tree growth of five apricot cultivars and reported that apricots grafted on Myrobalan appears to induce higher tree growth. Sitarek and Bartosiewicz (2011) grafted 'Morden 604' and 'Miodowa' apricot trees on the seedling rootstocks Wangenheim Prune and Erunosid, as well as Polish selection apricot genotypes A4 and M46 were compared with trees of the same cultivars on the standard $P$. divaricata rootstock. They reported that trees of both cultivars on $P$. divaricata and 'M46' had the largest trunk cross-sectional area and the most dwarfing rootstock was 'Wangenheim Prune'. Tworkoski and Fazio (2015) grafted scions of different apple cultivars to Malling (M.7, M.9, and M.27) and Geneva (G.935, G.5087, G.41, and G.11) rootstocks and reported that regardless of scion vigour, trees with G.935 and $\mathrm{G} .41$ rootstocks had the most height and diameter growth. Rather et al., (2018) reported that apple cultivar Vista Bella raised on the MM106 rootstock had the most mean shoot length of the current year, cultivars Vista Bella and Mollies Delicious had highest tree volume however the lowest tree volume was recorded in cultivar Cooper IV. They also reported that cultivars had a significant effect on the TCSA and maximum TCSA was 
observed in cultivar Starkrimson and minimum in cultivars Vista Bella and Cooper IV. Root growth is also vital to the survival of plants. Main functions of rootsystem are; roots anchor the plant in the soil, roots absorb water and mineral salts from the soil, roots may store food, roots form a passage way for water and dissolved substances from the root into the stem and also for foods from the stem down into the root and the synthesis of plant hormones. Almond seedling rootstocks are vigorous, deep rooted and typically tap rooted with few branches, whereas, peach root system tends to be somewhat shallow rooted, but with larger number of somewhat smaller roots (Kester and Grasselly, 1987). Redhaven peach on GF 677 had greater root number and more roots with greater than $10 \mathrm{~mm}$ diameter (Lichev and Govedarov, 1995).

\section{Yield and quality}

Fruit yield is the function of number of fruits produced by a tree and their weight however quality is the degree of excellence. Rootstock and scion combinations have variable influence on tree productivity and fruit quality. Donno et al., (1972, 1976) observed that almond cv. Tuono had more yield on sweet almond than on bitter almond seedling rootstock, however, this difference disappeared after 8-10 years. Higher almond yields were recorded on peach and peach $\mathrm{x}$ almond hybrid than on almond rootstock (Gall and Grasselly, 1979), on 2702, 2682, 2147, 8455 and 8475 rootstocks (Popak, 1987), in Carmel and Nonpareil on peach than on almond rootstock (Micke et al., 1996) and Ferragues than Texas and Tuono grafted on almond x peach hybrid GF677 and peach 305 (Monastra, 1976). Higher almond yields were also recorded in Ferragues grafted on almond, peach GF305 and peach x almond GF677 rootstock than in Tuono on almond rootstock (Barbera et al., 1994), Pizzuta d'Avala on Fasciunieddu Spammata (Alberghina, 1992),
Colorada and Clone Cebas on Garrigues rootstock (Egea Caballero and Burgos Ortiz, 1991). Nonpareil almond cultivar on peach and bitter almond rootstocks produced higher yields than on Behmi rootstock (Kumar, 1987; Dass, 1990). Highest fruit weight and size in Nonpareil, highest kernel percentage in IXL and Nonpareil, highest fat percentage in katha almond on wild peach rootstock and highest per cent proteins in Afganistan Seedling on bitter almond rootstock have been reported by Kumar (1987). Hrotko et al., (2001) evaluated the plum trees of cultivars 'Stanley', 'Cacanska lepotica' and 'Althan's Gage' planted on rootstocks: Myrobalan C 162/a' seedling, vegetatively propagated Marianna 'GF 8-1', Myrobalan 'MY-BO-1', Myrobalan 'MY-KL-A', 'St Julien' 'GF 655/2', and Prunus domestica 'Fehér besztercei' and observed that 'Stanley' produced highest yield efficiency on vigorous Marianna GF 8-1, medium yield efficiency was achieved on Myrobalan C 162/a seedling, MY-BO-1, MY-KL-A, and 'St Julien' GF $655 / 2$, low efficiency was on semi-dwarf 'Fehér besztercei'. However fruit weight on trees planted on different rootstocks was not significantly influenced. They found good yield efficiency and fruit weight of 'Althan's Gage' on 'St Julien' GF 655/2, medium on Marianna GF 8-1 and Myrobalan seedling C 162/a, while the MY-KL-A produced very low. Son and Kuden (2003) studied the influence of seedling and GF-31 rootstocks on the yield and quality of fruits of Tokalolu, Precoce De Tyrinthe, Joubert Foulon, Canino, Sakt 6, Beliana, Priana and Early Kishnevski table apricot cultivars and reported that fruit yields were highest on apricot seedling rootstocks for all cultivars. Fruit weight was also greater on seedling than GF-31. Dates of full blooming and maturation were earlier on grafted seedling rootstocks than those on GF31. Yahya Al-Hinani and Roper (2004) reported that Gala apple trees on M.26 EMLA had slightly higher yield in comparison to 
other rootstocks. Sharma et al., (2004) recorded higher yield of green almonds in Non Pareil almond cultivar than Merced cultivar when raised on wild peach than bitter almond rootstocks. Univer et al., (2006) observed that apple rootstocks B.9, B.396 and B.545 were earliest to start cropping than trees on M.26 and E.75. Lanauskas (2006) evaluated two plum cultivars 'Stanley' and 'Kauno Vengrine' raised on four rootstocks viz. Prunus cerasifera seedlings, St. Julien A, St. Julien GF 655/2 and Marianna GF 8/1 and recorded highest fruit yield and yield efficiency in trees grafted on Prunus cerasifera seedlings. However tested rootstocks had no influence average fruit weight. Wongtanet and Boonprakob (2010) studied the influence of nine peach rootstocks on growth of three scion cultivars and observed significant influence of rootstocks on scion height, branch weight and trunk size. Milosevic et al., (2011) conducted an experiment to determine the effects of Myrobalan rootstock and Blackthorn interstock on the productivity and fruit quality traits of five apricot cultivars and reported that apricots grafted on Myrobalan have better yield and fruit weight when compared with the Blackthorn.

Sitarek and Bartosiewicz. (2011) grafted 'Morden 604' and 'Miodowa' apricot trees on the seedling rootstocks Wangenheim Prune and Erunosid as well as Polish selection apricot genotypes A4 and M46 were compared with trees of the same cultivars on the standard $P$. divaricata rootstock. They reported that rootstock had no effect on the fruiting of 'Morden 604' trees however in Miodowa cultivar, the highest cumulative yields were obtained from trees grafted on P. divaricata and 'M46', and the lowest from those on 'Erunosid'. 'Wangenheim Prune', in comparison to other rootstock significantly reduced the mean fruit weight and the mean content of soluble solids in fruits of 'Morden 604' and 'Miodowa' apricots was not affected by rootstocks. Hajagos et al., (2012) studied combinations of 5 rootstocks ('GiSelA 5', 'GiSelA 6', 'Piku 1', 'PHL-C', and 'Weiroot 158') and 2 scions ('Regina' and 'Kordia') with regards to properties affecting consumer value, fruit appearance, and flavour. They reported that rootstock effect was clearly identifiable in the development of fruit firmness, fruit weight, and sugar and acid content and based on these properties, 'PHLC' was recommended for 'Kordia' scion. Bartolini et al., (2014) studied the influence of two commercial Prunus rootstocks ('Myrabolan 29/C' and apricot 'Seedling') on fruit entity and quality of 'Pisana' apricot cultivar and reported that rootstocks had no significant influence on the flowering and fruiting entity but rootstock 'Myrabolan 29/C' appeared to induce the highest fruit weight, total antioxidant capacity and total phenols. Ikinci et al., (2014) studied the influence of three quince (BA 29, Quince A and Quince C) and a local European pear seedling rootstocks on fruit quality of Santa Maria pear and observed higher fruit firmness on BA 29 and Quince A.

Mestre et al., (2017) studied quality of peach cv. 'Catherina' fruits raised on seven hexaploid plum rootstocks, as well as one Prunus persica seedling and observed that rootstocks Constantí 1 and Monpol generated greater cumulative yields however, the highest yield efficiency was recorded on GF 655/2 and Montizo, although they did not differ significantly from Adesoto and P. Soto 67 AD. They recorded highest average fruit weight on PM 105 AD and the lowest on GF $655 / 2$. However the highest soluble solids content were observed on the Pollizo rootstocks Adesoto and PM 105 AD, followed by P. Soto 67 AD. Rather et al., (2018) reported that apple fruits harvested from trees on MM-106 were significantly higher in quality parameters like weight, volume and yield compared to those on M-9 rootstock. 


\section{Chlorophyll content and photosynthesis}

Chlorophyll is a green pigment, present in all green plants which is responsible for the absorption of light to provide energy for photosynthesis which is a chemical process through which plants produce glucose and oxygen form carbon dioxide and water using only light as a source of energy. Rootstocks markedly influence the photosynthetic rate of scion variety. Syrbu et al., (1983) reported that photosynthesis was higher in trees on peach rootstock, medium on almond and apricot and lowest on cherry plum rootstock. Higher rate of photosynthesis in Redhaven peach trees on Lovell rootstock than on Siberian C rootstock (Yadava and McCarry, 1987), on GF677 rootstock than selfrooted plants Cappellini and Antonelli, 1997) was also observed. Apple plants grafted on seedling rootstocks had higher leaf chlorophyll a and b contents (Kultebaev, 1975) and photosynthesis (Barden and Ferree, 1979). Westwood and Zielinski (1966) found more chlorophyll content in Starkrimson than Starking Delicious cultivar of apple. Maximum photosynthetic productivity was found in the leaves of apple trees on dwarfing as compared to those on vigorous rootstocks (Titova and Shishkanu, 1976; Maidebura et al., 1978; Trunov and Muromtsev, 1980). Ferree et al., (1975) reported higher net photosynthesis in the leaves of Red Spur Delicious than in Rich-a-Red apples. Similarly, apple leaves on M9 rootstock had higher leaf chlorophyll content (Rud et al., 1977; Makariev et al., 1986; Chandel and Chauhan, 1994) and photosynthetic intensity (Andryushchenko et al., 1977) as compared to other rootstocks. Fallahi et al., (2001) reported that leaf photosynthesis was lower in the leaves of 'BC-2 Fuji' apple trees on Bud.9 rootstock than those on Ottawa 3 and M.7 EMLA rootstocks. Ghazvini et al., (2008) evaluated photosynthetic activity of three Iranian commercial pistachio cultivars on four rootstocks and observed that trees on Sarakhs and $P$. atlantica rootstocks had highest photosynthetic rates. Sharma and Joolka (2002) recoded higher leaf chlorophyll in Non Pareil almond on bitter almond rootstock than on wild peach rootstock however leaf photosynthesis was higher on wild peach rootstock.

\section{Transpiration and stomatal conductance}

First reaction to drought stress in most of the fruit plants is stomatal closure which prevent water loss through transpiration. This stomatal closure is mainly related to soil moisture content and is mainly controlled by chemical signals such as abscisic acid production in dehydrating roots. Rootstock and scion influence tree productivity by affecting tree water balance (Giulivo and Bergamini, 1981). On M7 rootstock, Golden Delicious apple had highest stomatal conductance (Giulivo et al., 1985). Similarly, Starking Delicious on M7 had least stomatal resistance and highest transpiration while a reverse trend was recorded in MM111 rootstock (Chandel and Chauhan, 1992). Stomatal conductance of Empire apple on M26 rootstock was generally lower than on other rootstocks (Olien and Lakso, 1986). However, Alleyne et al., (1989), while comparing water relation of ungrafted container grown M2, M7, M9, M13, M26, MM106 and MM111 rootstocks, found that leaf conductance was higher in M26 than the other rootstocks. Marro and Cereghini (1976) concluded that guard cells in apple trees on M9 were more responsive in controlling transpiration than those on seedling rootstocks. In contrary to this, Barden and Ferree (1979) observed no significant effect of apple clonal rootstocks on stomatal conductance and transpiration of Starking Delicious apple. However, Higgs and Jones (1991) reported highest leaf conductance and the lowest leaf water potential in James 
Grieve apple in comparison to fifteen other apple cultivars studied. Sharma et al., (2004) recorded higher leaf stomatal conductance and transpiration rate in Non Pareil almond cultivar than Merced cultivar when raised on wild peach than bitter almond rootstocks.

\section{Stomatal size and density}

Stomatal size and density alter water relations in different fruit crops. These parameters are markedly influenced by the rootstock scion combinations. Among the various almond cultivars, Katha had the highest and Afganistan Seedling had the lowest stomatal density, whereas among different rootstocks, wild peach had the maximum and bitter almond the minimum stomatal density in various scion cultivars (Kumar, 1987).However, stomatal length was maximum in almond trees on bitter almond and minimum in those on Behmi rootstock, whereas, stomatal diameter was maximum in trees 'on Behmi and the minimum in those on bitter almond rootstock. In clonal rootstocks of plum, Pathak et al., (1977) observed that stomatal number were more in vigorous rootstock Myrobalan A and less in dwarfing rootstock Damas C. Pejkje (1973) reported that Stanley, California and Imperial cultivars of plum had higher stomatal number per unit leaf area, while Pozegaca selection had the bigger stomata. Sharma and Joolka (2002) recoded higher stomatal density in Non Pareil almond leaves on wild peach rootstock than on bitter almond rootstock.

\section{Abscisic acid and proline contents}

Abscisic acid maintains the existence of plants under water stress through stomata closure however proline, a proteinogenic amono acid is used in the biosynthesis of proteins and act as osmoprotectant in stress tolerance. Rootstocks of different fruit crops influence abscisic acid and proline content of scion cultivars grafted onto them. Many workers (Grienenko and Zavalko,1967; Robitaille, 1971) reported that leaves of scion cultivars grafted on dwarfing rootstocks contained higher amounts of growth inhibitors than those on vigorous rootstocks. Yadava and Dayton (1972) studied the relation of endogenous abscisic acid to the dwarfing capacity of M9, M7, M1 and M16 and found a strong inhibitory substance in bioassay at or close to $\mathrm{Rf}$ values reported for maximum ABA activity. Highest inhibitor activity was observed in M9 tissue extract while it was progressively lower in M7, M1 and M16 rootstocks. Yadava and Lockard (1977) observed that trees grown on M9 and MM111 rootstocks contained highest and lowest levels of ABA like substances, respectively. Similar observations in Starking Delicious apples grown on M9 rootstock have been recorded by Rana (1985), Chandel and Chauhan (1991) and Robitaille and Carlson (1976). Chandel and Chauhan (1991) also observed higher leaf proline in Starking Delicious apple grown on M9 and MM111 rootstocks. Tworkoski and Fazio (2015) grafted scions of different apple cultivars to Malling (M.7, M.9, and M.27) and Geneva (G.935, G.5087, G.41, and G.11) rootstocks to measure abscisic acid in xylem exudates and found lower ABA in xylem exudate of 'Fuji' grown on G.935 and G.41 than G.5087 and G.11 rootstocks. Sharma and Joolka (2004) recoded higher leaf ABA and proline content in Non Pareil almond on bitter almond rootstock than on wild peach rootstock.

\section{Carbohydrates content}

Metabolism of sugars is crucial for abiotic stress tolerance in plants. Sugars are also the most important regulators that facilitate many physiological processes, such as photosynthesis, flowering, seed germination, senescence and other under various abiotic stresses. Rootstock and scion combinations 
exhibit significant influence on carbohydrate content. Nyujto and Brunner (1964) in apricot, observed that rootstocks inducing more vigorous growth had a lower carbohydrate content than those inducing less vigorous growth. Cherry plum trees on apricot resulted in higher leaf carbohydrate accumulation than on almond or cherry plum rootstock (Lishchuk, 1975). Layne and Ward (1978) reported higher levels of total carbohydrates and reducing sugars in apical shoots of Redhaven peach when grafted on Sibarian C rootstock than on Harrow Blood seedlings. Napoleon cherry on Mazzard rootstock had significantly lower starch content above and below the graft union than those on Mahaleb (Carison and Kyung, 1969). However, sour cherry grown on their own roots had higher sugar content than on Skorospelka and Brunner seedling rootstocks (Strelets, 1978). In apple, Brown et al., (1985) noted that the trees on MM111 rootstock contained significantly higher carbohydrates than those on M9 rootstock. However, Starking Delicious apple trees grown on M9 had the highest while those on M25 had the lowest leaf carbohydrate content (Chandel and Chauhan, 1991). Red Spur Delicious apples on M4 rootstock had the highest leaf total sugar than in Vance Delicious, whereas, Vance Delicious apples had higher leaf starch content on MM106 than in Red Spur Delicious (Bhatia, 1992).

\section{Nutrient uptake}

Rootstocks influence the nutrient content in the leaves of scion cultivar in different temperate fruit crops. The effect of rootstocks on the uptake of different nutrients by scion cultivar is reviewed as under:

\section{Nitrogen}

Nitrogen is an essential component of protein, chlorophyll and protoplasm and stimulate vegetative and root growth in fruit plants. Rootstocks exert marked influence on the $\mathrm{N}$ status of scion cultivar. Almond trees on wild peach rootstock had higher leaf $\mathrm{N}$ (Holves et al., 1985; Dass, 1990; Upadhayay and Ananda, 1991). Significantly higher leaf N content has been recorded in own rooted Redhaven than in Redhaven peach on Bailey, in Loring on Siberian C than on Nemaguard (Couvillon, 1982), in Italian prune on plum than on peach (Chaplin et al., 1972) and sweet cherry cv. Bing on Mazzard than those raised on GI 195/1 and 196/4 rootstocks (Neilsen and Kappel, 1996). However, Knowles et al., (1984) found only small and inconsistent difference in foliar $\mathrm{N}$ content of Loring and Redhaven peach trees on 5 seedling rootstocks. No significant difference in the $\mathrm{N}$ content of plum grown from suckers, on MyrobaJan (Dzamic et al., 1966) and seedling rootstocks (Vitanova, 1982) could be recorded. Sharma et al., (2007) recorded higher leaf $\mathrm{N}$ content in almond leaves raised on wild peach than on bitter almond rootstock.

\section{Phosphorus}

Phosphorus is a component of energy compounds ADP and ATP and is important for growth, flowering, fruiting and seed formation in fruit plants. In almond, rootstocks did not show any significant differences in leaf P (Dass, 1990; Upadhayay and Ananda, 1991). However, on hybrids as well as commercial rootstocks, the leaves of compatible rootstock scion combinations had higher $\mathrm{P}^{32}$ concentrations than those on ungrafted plants used as control. Leaves of incompatible combinations had lower $\mathrm{P}^{32}$ concentration than the control (Mitasov et al., 1973). Stanley plum trees grown on Zhlta Dzhanka (Prunus cerasifera) rootstock had reduced leaf $\mathrm{P}$ content (Vitanova, 1982). There was higher accumulation of $\mathrm{P}$ in scion leaves of plum on bitter almond and Behmi 
rootstocks (Sharma, 1988) and in Bing sweet cherry on GM9 than on GM 61/1 rootstock (Neilsen and Kappel, 1996). However, Hanson and Perry (1986) in an experiment with Montmorency cherries on seedling Mazzard and Mahaleb rootstock, found lower concentrations of leaf $\mathrm{P}$ on Mazzard than on Mahaleb rootstock. Sharma et al., (2007) recorded higher leaf $\mathrm{P}$ content in almond leaves raised on wild peach than on bitter almond rootstock.

\section{Potassium}

Potassium is an enzyme activator, regulate water relations and improve photosynthesis and development in fruit plants. Leaf $\mathrm{K}$ content is markedly influenced by different rootstocks. Leaf $\mathrm{K}$ content was lower in Carmel and Nonpareil almond grafted on almond than on Nemaguard and Lovell peach rootstocks (Micke et al., 1996), in almond on almond than on peach rootstock (Holeves et $a l .$, 1985), in Bing Sweet cherry on GM9 than on GM61/1 rootstock (Neilsen and Kappel, 1996). However, Dass (1990) and Upadhayay and Ananda (1991) observed higher leaf K levels in almond plants on bitter almond rootstock. Fallahi et al., (2001) reported that 'BC-2 Fuji' apple trees on M.7 EMLA rootstock had significantly higher leaf $\mathrm{K}$ than those on Ottawa 3 and Bud-9 rootstocks. Sharma et al., (2007) recorded higher leaf K content in almond leaves raised on wild peach than on bitter almond rootstock.

\section{Calcium}

Calcium is a constituent of cell wall and is important in the formation of cell membrane. Rootstocks produce variable effects on leaf $\mathrm{Ca}$ contents of scion cultivar. Higher leaf $\mathrm{Ca}$ content was estimated in almond trees on wild peach than on bitter almond rootstock (Dass, 1990; Upadhayay and Ananda, 1991), on almond than on peach rootstock (Micke et al.,
1996). Peach trees on Siberian C rootstock had reduced foliar $\mathrm{Ca}$ levels than on other rootstocks (Werner and Young, 1987). Whereas, Car et al., (1995) found higher leaf Ca content of Maravilha peach on Hansen 536 than on Harrow Blood; Mrs 2/5 or PSB2 rootstocks. Similarly Vitanova (1982) reported lower $\mathrm{Ca}$ content of Stanley plum raised on M"tna Boyaka Rakiinitsa (Prunus domestica) rootstock. However, Sharma (1988) observed higher accumulation of leaf $\mathrm{Ca}$ on Behmi and Myrobalan B rootstocks. Hanson and Perry (1986) found that the leaves of the Montmorency cherry on Mazzard contained higher Ca content than on Mahaleb. Similarly, Rozpara et al., (1989) observed lower $\mathrm{Ca}$ content in the leaves of sweet cherry grafted on Prunus mahaleb as compared to those on Prunus avium rootstocks. Fallahi et al., (2001) reported that 'BC-2 Fuji' apple trees on Bud-9 rootstock had significantly higher leaf $\mathrm{Ca}$ than those on M.7 EMLA and Ottawa 3 and rootstocks. Sharma et al., (2007) recorded higher leaf Ca content in almond leaves raised on wild peach than on bitter almond rootstock.

\section{Magnesium}

Magnesium regulates the processes of photosynthesis and carbohydrates metabolism and is also associated with protein synthesis. $\mathrm{Mg}$ content of the scion leaves was also influenced by the rootstock used. Higher leaf $\mathrm{Mg}$ in almond grafted on wild peach than on bitter almond and Behmi rootstocks (Dass, 1990) and on peach than on almond rootstock (Holeves et al., 1985; Micke et al., 1996) has also been recorded. However, Upadhayay and Ananda (1991) observed that rootstock did not influence leaf $\mathrm{Mg}$ content in the scion cultivars of almond. It has also been observed that there was higher accumulation of $\mathrm{Mg}$ in the leaves of plum on Behmi and Myrobalan rootstock (Sharma, 1988), Bing Sweet cherry on GM9 than on GM61/1 rootstock (Neilsen 
and Kappel, 1996), Sweet cherry on Prunus avium than on Prunus mahaleb rootstock (Rozpara et al., 1989) and Montmorency cherry on Mahaleb than on Mazzard rootstock (Hanson and Perry, 1986). Fallahi et al., (2001) reported that 'BC-2 Fuji' apple trees on M.7 EMLA rootstock had significantly higher leaf $\mathrm{K}$ than those on Ottawa 3 and Bud-9 rootstocks. Sharma et al., (2007) recorded higher leaf $\mathrm{Mg}$ content in almond leaves raised on wild peach than on bitter almond rootstock.

\section{References}

Alberghina, O. 1992. Productive ability of 31 almond cultivars on two rootstocks in an environment on the ionic coast of Sicily. Rivista di Fruitt. e di orto., 54(1): 69-74.

Al-Hinani, Yahya K. and Teryl R. Roper. 2004. Rootstocks effects on growth and quality of 'Gala' apples. HortScience39 (6); 1231-1233.

Alleyne, V., Larsen, E. and Higgins. S. 1989. Water relations of container grown virus tested and common apple rootstocks. Scientia Hortic., 38:

Andryushchenko, D.P., Shishkanu, T.V., Titova, NV.and Bokovan, I.P. 1977. The effect of the rootstock on the growth and photosynthesis of apple transplants. Plodovoe Pitomnikovodstvo Moldavii, 95: 102.

Atanasov, A.T. 1974. Studies on the root system of apple trees grafted on different rootstocks. Grad. i Loz. Nauka, 11 (8): 14-22.

Barbera, G., Mareo, L.D., La Mantia, T. and Schirra, M. 1994. Effect of rootstock on productive and qualitative response of two almond varieties. Acta Hortic., 373: 129-134.

Barden, J.A. and Ferree. D.C. 1979. Rootstock does not affect net photosynthesis, dark respiration, specific leaf weight and transpiration of apple leaves. J. Amer. Soc. Hort. Sci., 104: 526-528.

Barroso, J.M. and Renaud, R. 1994. Preliminary result of plum rootstock trials in Portugais. Acta Hortic., 359: 237-242.

Bartolini, S., Leccese, A., Lacona, C., Andreini, L. and Viti, R. 2014. Influence of rootstock on fruit entity, quality and antioxidant properties of fresh apricots cv. 'Pisana'. New Zealand Journal of Crop and Horticulture 42(4): 265-274.

Beakbane, A.B. and Majumdar. P.K. 1975. A relationship between stomatal density and growth potential in apple rootstocks. J. Hort.Sci., 50: 285-289.

Bellini, E., Begnami, C., Nalali, S. and Moretu, G. 1993. Comparison of ten peach rootstocks on the Lazio marshes. In 21 st convegno Perchicolo, Lugo, Reven"na, Italy.

Bhatia, S. K. 1992. Effect of paclobutrazol, daminozide and rootstocks on the growth and chemical composition of apple plant. Ph. D. Thesis, Dr. Y.S. Parmar University of Horticulture and Forestry, Nauni, Solan, India.

Brown, C. S., Young, E. and Pharr, D.M. 1985. Rootstock and scion effects on the seasonal distribution of dry weight and carbohydrates in young apple trees. J. Amer. Soc. Hort. Sci., 110: 696-701.

Bussi, C., Huget, J. G., Besset, J. and. Girard, T. 1995. Rootstock effects on the growth and fruit yield of peach. European J. Agron., 4(3): 387-393.

Cappellini, P. and Antonelli, M. 1997. Photosynthetic response to light levels is influenced by peach genotype rootstock combinations. Advances in Horticultural Sci., 11 (2): 67-69.

Car, T., Inglese, P., Gwvannin, D. and Truce, E. 1995. Rootstock influence on dry matter and nutrient above ground 
content and partitioning in Maravilha peach trees. Acta Hortic., 383: 105-114.

Carison, R. F. and Kyung, Yu. 1969. Starch content in cherry stems near loci of graft, banding and scoring. HortSci., 4: 246-248.

Chandel, J. S. and Chauhan, J. S. 1992. Drought resistance of Starking Delicious apple plants on different rootstocks. Indian J. Hort., 49(4): 294299.

Chandel, J.S. 1989. Effect of different rootstocks and moisture levels on growth, water relations and nutrient uptake of container grown apple plants. Ph. D. Thesis, Dr. Y.S. Parmar University of Horticulture and Forestry, Nauni, Solan, India.

Chandel, J.S. and Chauhan, J.S. 1991. Accumulation of proline, ABA and carbohydrate contents in Starking Delicious apple on clonal rootstocks and their correlation with drought resistance. Prog. Hort., 23 (1-4): 5-11.

Chandel, J.S. and Chauhan, J.S. 1994. Effect of rootstocks and soil moisture stress on biomass, root growth and photosynthetic efficiency of apple. Prog. Hort., 26 (3-4): 136-140.

Chaplin, M.H., Westwood, M.N. and Roberts, A.N. 1972. Effects of rootstock on leaf element of Italian prune (Prunus domestica L.). J. Amer. Soc. Hort. Sci., 97: 641-644.

Couvillon, G.A. 1982. Leaf elemental content comparisons of own-rooted peach cvs. to the same cvs. on several peach seedling rootstocks. J. Amer. Soc. Hort. Sci., 107(4): 555-558.

Dass, B. 1990. Influence of rootstock and scion cultlvar on the uptake and removal of nutrients by almond trees. M. Sc. Thesis, Dr. Y. S. Parmar University of Horticulture and Forestry, Nauni, Solan, India.

Donno, G., Godini, A. and Ferrara, E. 1976.
Sweet and bitter almond seedling rootstocks and their influence on the development and yield of almonds. Annali della Facolta di Agraria, Universita di Bari,28: 123-128.

Donno, G., Godini, A.and Ferrara, E. 1972. Comparison between the growth of sweet and bitter almond seedling rootstocks and their effect on growth, yield and nut: kernel ratio in almond (Preliminary contribution): Annali della Facolta di Agraria, Universita di Bari, 25: 513-518.

Dozier, W.A. Jr., Carlton, C.C., Short, K.C., Snell, J.M., McGuire, J.A. and Evans, C. E. 1983. Rootstock influence on growth, yield and survival of Loring peach trees on an old peach site. J. Amer. Soc. Hort. Sci., 108(2): 250-252.

Dzamic, H., Popovic, Z. and Pantelic, M. 1966. The nitrogen, phosphorus and potassium contents of plum leaves. Zborn. Rad. Poljopriv. Fak. Beograd, 14: 1-14.

Egea Caballera, J. and Burgos Ortiz, L. 1991. Comparative study of some almond rootstocks. ITEA Production Vegetal., 87(1): 36-40.

Fallahi, E., Neilsen, G.H., Chun, IK-Jo and Colt, W.M. 2001. Effect of three rootstocks on photosynthesis, leaf mineral nutrition and vegetative growth of "BC-2 Fuji" apple trees. Journal of Plant Nutrition, 24(6): 827-834.

Ferree, D.C., Morrison, C.A. and Show, L.C. 1975. Red Delicious apple trees which strain is best? Rep. Chia Agric. Hort. Dept. Agric. Home Econ. Nat. Res., 60(2): 19-22.

Gall, H. and Grasselly, C. 1979. Trial on the behaviour of 12 almond varieties grafted on almond, peach and peach $\mathrm{x}$ almond rootstocks. Station d' Arboriculture Fruitiere, 215-227.

Ghazvini, R.F., Sajadian, H. and Holemabadi, H. 2008. Effects of some pistachio 
rootstocks on leaf photosynthesis rate of three Iranian commercial pistachio cultivars. Acta Hortic. 772: 241-244.

Giulivo, C. and Bergamini, A. 1981. Caratteristiche fisielogiche del melo e tecnica irriguu. Economia Trentina, 3: 69-73.

Giulivo, C., Ponchia, G., Gianola, A. and Pitacco, A. 1985. Effect of rootstock on water balance of Golden Delicious apple. Acta Hortic., 171: 399-404.

Glucina, P.G., Mills, R.S. and Manson, P.J. 1992. Comparison of the growth, yield, fruit size and survival of 'Golden Queen' peach on seven rootstocks. New Zealand J. Crop Hort. Sci., 20(3): 297 303.

Grienenko, V.V. and Zavalko, L.B.. 1967. Physiological requirement and productivity of dwarf apple trees. Sodovodstvo, 4: 36.

Grzyb. 1989. The mineral nutrient content in the leaves of two cherry cultivars with interstem. In abstracts of contributed paper, International Symposium on Diagnosis

of Nutritional Studies of Deciduous Fruit Orchard, Warsaw, Poland, p.58.

Hajagos, Aniko, Spornberger, A., Modl. P. and Vegvari, G. 2012.The effect of rootstocks on the development of fruit quality parameters of some sweet cherry (Prunus avium L.) cultivars, 'Regina' and 'Kordia', during the ripening process. Agriculture and Environment, 4: 59-70.

Hanson, E.J. and Perry, R.L. 1986. Comparison of nutrient uptake efficiency of Mazzard and Mahaleb cherry rootstock. In Abstrcts of contributed paper, Proc. 22nd Int. Hort. Cong., Davis, USA Abst. No.68, p.117.

Higgs, K. H. and Jones, H. G. 1991. Water relations and cropping of apple cultivars on dwarfing rootstock in response to imposed drought. J. Hort. Sci., 66(3):
367-379.

Holeves, C.D., Stylianides, D.C. and Michaelides, Z. 1985. Nutrient element variability in the leaves of almond trees in relation to variety, rootstock and vegetative parts of the tree. Options Mediterraneannes NO.1: 111-120.

Hrotkó, K., Magyar, L., Klenyán, T. and Simon, G. 2001. Effect of rootstocks on growth and yield efficiency of plum cultivars. Acta Hortic.: 577.

Ikinci, A., Bolat, I., Ercisli, S. and Kodad, O. 2014. Influence of rootstocks on growth, yield, fruit quality and leaf mineral element contents of pear cv. Santa Maria in semi-arid conditions. Biol. Res. 47.

Kemp, H. and Wertheim, S.J. 1996. First results of two international cherry trial. Acta Hortic., 410: 167-176.

Kester, D. W. and Grasselly, C. 1987. Almond rootstocks. In: Rootstocks for fruit crops, (R. C. Rom and R. F. Carlson eds.). John Willey and Sons, New York, pp.265-293.

Knowles, J.W., Dozier Jr., W.A., Evans, C.E., Carlton, C.C. and McGuire, J.M. 1984. Peach rootstock influence on foliar and dormant stem nutrient content. J. Amer. Soc. Hort. Sci., 109: 440-444.

Kosina, J. 1994. Growth and bearing of 'Stanley' plum on clonal myrobalans and 'Damas C' rootstock. Acta Hortic., 359: 249-255.

Koval, A.T. 1977. Root system of vegetatively propagated rootstocks. Sadovodstvo Vinogradarstvo i Vinodelie Moldavic, 5: 33-35.

Kultebaev, E.T. 1975. The effect of seedling rootstocks on the accumulation of chlorophyll $\mathrm{a}$ and $\mathrm{b}$ in Aport aleksandra leaves. Izvestija AN Kazssr Biol., 4: 2123.

Kumar, S. 1987. Effect of rootstock and scion cultivars on foliar nutrient status in almonds. M.Sc. Thesis, Dr. Y.S. Parmar 
University of Horticulture and Forestry, Nauni, Solan, India.

Lanauskas, J. 2006. Effect of rootstock on growth and yield of plum trees cv. 'Stanley' and 'Kauno Vengrine'. Sosininkyste IR Darzininkyste 25(3): 243-249.

Layne, R. E. C. and Ward, G. M. 1978. Rootstock and seasonal influence on carbohydrates levels and cold hardiness of Redheaven peach. J. Amer. Soc. Hort. Sci., 103 (3): 408-413.

Lichev, V. and Govedarov, G. 1995. Investigation of root system of peach rootstock in a nursery. Rasteniev dn Nauki, 32(5): 264-267.

Lishchuk, A.I. 1975. Changes in carbohydrates solubility in the leaves of cherry plums on different rootstocks. Sadivnitstvo Resp. Mizhuid Temat. Zbornik., 22: 155-158.

Maidebura, V.I., Kumpan, E.D. and Aleksandryvk, M.Y. 1978. The assimilating area of the apple cultivar Reinette de champagne in relation to the rootstock. Nauchnye Trudy Ukr. S-Kh. Akad. No.220: 39-41.

Makariev, Z., Milanov, B. and Doichev, K. 1986. Photosynthetic potential and productivity of Golden Delicious apple trees grown under various cultural systems. Rasteniev dril Nauki, 23(3): 71-76.

Marro, M. and Cereghini, F. 1976. Observations on various morphological and functional aspects of spurs on Richared apples on seedling and M9 rootstocks. Rivista della orto. Italiana, 60 (1): 1-14.

Mestre, Lucía, Reig, Gemma, Betrán, Jesús A. and Moreno, María-Angeles. 2017. Influence of plum rootstocks on agronomic performance, leaf mineral nutrition and fruit quality of 'Catherina' peach cultivar in heavy calcareous soil conditions. Spanish Journal of
Agricultural Research 15(1): 1-11.

Micke, W.C., Freeman, M.W., Beede, R.H., Kester, D.E., Yeager, J.T., Pelletreau, K.G. and Conelle, J. H. 1996. Almond trees grown on peach rootstock initially more productive. California Agric., 50(4): 29-31.

Milosevic, T., Milosevic, N. and Glisica, I. 2011. Influence of stock on the early tree growth, yield and fruit quality traits of apricot (Prunus armeniaca L.). Journal of Agricultural Sciences 17: $167-176$.

Mitasov, I.M., Rikhter, A.A., Chemaarin, N.G. and Yaroslavtseva, I.P. 1973. Studies on the compatibility of almond with hybrid rootstocks. Sel'Skokhozyaistvennaya Biologiya, 8: 780-781.

Mitov, P. and Dyakov. O.S. 1989. The effect of different seedling and clonal rootstocks on the growth and reproductive development of peach cultivar Babygold 6. Rasteniev dui Nauki, 26(7): 65-69.

Monastra, F. 1976. A comparative trial of 8 almond cvs. grafted on various rootstocks. Annali della Instituto Spermenlate perla Frutticoltura, 7: 8593.

Neilsen, G. and Kappel, F. 1996. Bing sweet cherry leaf nutrition as affected by rootstock. Hort. Sci., 31 (7): 1169-1172.

Nyujto, F. and Brunner, T. 1964. Preliminary evaluation of physiological studies conducted on apricot rootstocks in the nursery stage. DunaTisza Kozi mezogazd Kiseri Int. Evk., Kecskemet., pp.149-156.

Olien, W.C. and Lakso, A.N. 1986. Effect of rootstock on apple tree water relations. Physiol. Plant, 67: 421-430.

Parnia, P., Radulescu, C., Movileanu, M., Stanciu, N. and Mladin, G. 1977. Research on the development of the root system of apple trees grafted on 
different rootstocks and interstocks. Lucrarile Stiintifice ale institutulue de Cercetari pentru Pomicultura Pitesti., 6: 149-158.

Pathak, R.K., Pandey, D.and Pandey, V.S. 1977. Stomatal distribution as an index for predicting vigour of plum rootstocks. Indian J. Hort. 34(2): 117 119.

Pejkje, B. 1973. Investigation on stomatal and fruit size in certain plum cultivars (Prunus domestica). Godisen Zboruik na Zem. Kiet Fakultet na Univ. Ovestarstue., 25: 71-75.

Popak, N.G. 1987. Productivity of almonds on skeletal soils in relation to rootstocks. Sbornik Nauchnykh Trudov Gosudarstvennogo Nikitskogo Botanicheskogo sada, No.102: 79-87.

Rana, G.S., Daulta, B.S. and Rana, K.S. 1997. Effect of rootstocks and drip irrigation on trunk diameter of peach (Prunus persica Batsch.) under high density plantation. Annals Agric. Res., 18(2): 231-233.

Rana, S.S. 1985. Physiological studies on clonal rootstocks and scion interrelation in apple. Ph.D. Thesis, HPKW, Palampur, India. Rozpara, E., T.Olszewski and Z.S.

Rather, J.A., Misgar, F.A., Dar, G.A. and Qurashi, S.N. 2018. Effects of rootstocks on horticultural characteristics of various exotic apple cultivars in Kashmir climatic conditions.

Int.J.Curr.Microbiol.App.Sci. 7(04): 2341-2348.

Renaud, R. and Salesses, G. 1994. Interspecific hybridization and rootstock breeding for European plums. Acta Hortic., 359: 97-100.

Robitaille, H.A. 1971. The relationship of endogenous hormones to growth characteristics and dwarfing in Malus. Ph. D., Thesis, Mich. St. Univ. East
Lansing, Mich.

Robitaille, H.A. and Carlson, R.F. 1976. Gibberellic and abscisic acid like substances and regulation of apple shoot extension. J. Amer. Soc. Hort. Sci., 101 (4): 388-392.

Rud, G.Y., Tanasev, V.K., Barbarosh M.N. and Puris, M.P. 1977. Leaf formation and chlorophyll content in the leaves of the apple cultivar Jonathan in relation to rootstock, spacing and rates of preplanting fertilizer. Reterativnji Zhurnal, 2.55:583.

Sadowski, A., Dziuban, R., Kowalik, P., Kramarcxyk, W., Lunieswka, B. and Wojtalewska, E.. 1987. Potassium nutrition of apple and sour cherry nursery trees as affected by rootstock, cultivar and fertilization. J. Plant Nutr., 10: 20-25.

Salvador, F.. De, R. and Monastra, F. 1996. Agronomic evaluation of different peach rootstocks. Acta Hortic., 374: 195- 200.

Senin, V.I., Rastorguev, A B. and Vodyanitskii, V.I. 1989. The effect of irrigation on the root system of apple transplants in the nursery. Sadovodstvo - i - vinogradarstvo, 6: 31-34.

Sharma, M.K., and Joolka, N.K. 2002. Effect of bioregulators and rootstocks on growth, photosynthetic efficiency and water relations of Nonpareil almond. Annals of Agricultural Research, 23(4): 740-743.

Sharma, M.K. and Joolka, N.K. 2004. Screening of almond rootstocks for drought tolerance. The Hort. Journal, 17(3): 191-197.

Sharma, M.K., Joolka, N.K. and Singh, S.R. 2007. Growth, yield and leaf nutrient status of almond as affected by scion, rootstock and soil moisture. Environment \& Ecology, 25(1): 62-64.

Sharma, M.K., Joolka, N.K. and Sushil 
Kumar. 2004. Growth, water relations and productivity of almond as influenced by scion, rootstock and soil moisture. Agric. Sci. Digest,; 24(2): 115-117.

Sharma, R P. 1988. Reciprocal influence of rootstock and scion on growth and mineral composition of stone fruits. Ph. D. Thesis, Dr. Y. S. Parmar University of Horticulture and Forestry, Nauni, Solan, India.

Sitarek, M., Grzyb, Z.S. and Kozinski, B. 1995. Growth and yield of two plum cultivars on different rootstock in the first three years after planting. Mat. Ogo. Kon. nav. Nauka Pra. Ogro., 131134.

Sitarek, Mirostaw and Bartosiewicz, Barbara. 2011. Influence of a few seedling rootstocks on the growth, yield and fruit quality of apricot trees. Journal of Fruit and Ornamental Plant Research 19(2): 81-86.

Son, Levent and Kuden, Ali. 2003. Effects of seedling and GF-31 rootstocks on yield and fruit quality of some table apricot cultivars grown in Mersin. Turk. J. Agric. 27 (2003) 261-267.

Stoilov, G., Marinov, P. and Oimitrova, M. 1979. Effect of rootstock and cultivar on the nutrient element content of apricot leaves. Gradinarska i Lozarska Nauka, 16: 28-32.

Strelets, V.O. 1978. Physiological and biochemical characteristics of grafted. and non-grafted sour cherry and plum trees. Vestnik Sel'skokhoz-yaistvennol Nauki., 12: 70-75.

Syrbu, I. G., Stoyanov, G. L. and Pitushkam, S. G. 1983. Characteristics of photosynthesis in peach trees on different rootstocks. Sadov Vinovino Moldavii, 9: 50-51.

Titova, N.V. and Shishkanu, G.V. 1976. Photosynthesis and pigment content in apple trees on different rootstocks.
Referativnyi Zhurnal, 9.55: 825.

Trunov, L.A. and Muromtsev, L.A. 1980. Effect of rootstock on the activity of the root system and on photosynthesis in apple trees. Sadovodstvo Uinograelarstuo i Vinodelie MoldaviL, 9: 28-29.

Tworkoski, T. and Fazio, G. 2015. Effects of size-controlling apple rootstocks on growth, abscisic acid, and hydraulic conductivity of scion of different vigor. International Journal of Fruit Science, 15(4): 369-381.

Tworkoski, T. and Miller, S. 2007. Rootstock effect on growth of apple scions with different growth habits. Scientia Horticulturae 111(4): 335-343.

Univer, Neema, Univer, Toivo and Tiirmaa, Krista. 2006. Effect of five rootstocks on growth and yield of four apple cultivars in young orchard. Sodininkyste Ir Darzininkyste 25(3): 192-198.

Upadhayay, S.K. and Ananda. S.A. 1991. Effect of rootstock and scion cultivars on the macro-nutrient content in almond leaves. Indian J. Hort., 48(4): 309-311.

Vegera, A.A. 1982. Distribution of the root system of apple trees grafted on M25 in the fruit-Sovkhoz Leshnaya Dacha. Referativnyi Zhurnal, 8.55: 628.

Vitanova, I. 1982. Effect of rootstock on the nitrogen and mineral element contents in the leaves of the plum cv. Stanley. Gradinarska i Lozarska Nauka, 19(1): 34-40.

Werner, D.J. and Young, E. 1987. Effect of 'Siberian $\mathrm{C}^{\prime}$ rootstock, interstem and scion on foliar calcium content in peach. Fruit Var. J., 41: 140-141.

Westwood, M.N. and Zielinski, O.B. 1966. Comparative growth habit and leaf composition of a compact mutant and standard Delicious apple. Proc. Amer. Soc. Hort. Sci., 88: 9-13.

Wongtanet, D. and Boonprakob, U. 2010. 
Effect of rootstocks on growth of peaches in the highland of northern Thailand. Acta Hortic. 872, 327-332.

Yadava, U.L. and Dayton, D.F. 1972. The relation of endogenous abscisic acid to the dwarfing capability of East Mailing apple rootstocks. J. Amer. Soc. Hort. Sci., 97: 701-705.

Yadava, U.L. and Lockard, R.G. 1977. Abscisic acid and gibberellin in three (Malus sylvestris) rootstock clones. Physiol. Plant, 40: 225-229.
Yadava, U.L. and McCarry, D. 1987. Phytohormones influence gas exchange activities and short life related performance of peach trees in the orchard. Proc. Pl. Growth Reg. Soc. America: 395-403.

Ystass, J. and Froynes, O. 1993. Performance of five plum rootstocks over 17 years to five commercial important plum cultivars in Norway. Norwegian J. Agric. Sci., 7(3-4): 267-274.

\section{How to cite this article:}

Sharma, M.K., Rifat Bhat, N. Nazir, A. Khalil, S.A. Simnani and Sundouri, A.S. 2019. Techniques for Determination of Vitamin $\mathrm{B}_{6}$, Vitamin $\mathrm{C}$ and Variability in Areca Nut (Areca catechu) Samples of Karnataka, India. Int.J.Curr.Microbiol.App.Sci. 8(02): 1089-1104.

doi: https://doi.org/10.20546/ijcmas.2019.802.128 